\title{
Equity fund flows and stock market returns in the USA before and after the global financial crisis: a VAR-GARCH-in-mean analysis
}

\author{
Vassilios Babalos $^{1} \cdot{\text { Guglielmo Maria } \text { Caporale }^{2} \text { (D) Nicola Spagnolo }}^{2}$
}

Received: 27 June 2018 / Accepted: 3 October 2019 / Published online: 12 November 2019

(c) The Author(s) 2019

\begin{abstract}
The 2008-2009 global financial crisis has raised new questions about the relationship between equity fund flows and stock market returns. This paper provides new insights by using US monthly data over the period 2000:1-2015:8 and estimating a VAR$\operatorname{GARCH}(1,1)$-in-mean model with a BEKK representation, which also includes a switch dummy for the global financial crisis. We find causality-in-mean from stock market returns to equity fund flows (consistently with the feedback-trading hypothesis) only in the post-September 2008 period. There are also volatility spillovers from stock market returns to equity fund flows both before and after the crisis; however, this relationship is not stable, becoming weaker in the crisis period. As a robustness check, we augment the model with a set of macroeconomic control variables. Their inclusion does not affect the main results.
\end{abstract}

Keywords Equity fund flows · Stock market returns · Volatility ·

VAR-GARCH-in-mean model

JEL Classification G23 · C32

\section{Introduction}

It has long been recognised that capital markets are dominated by institutional investors: In the USA, the demand for mutual fund shares has experienced a steadily, upward trend from 2006 to 2015; households invested an annual average of \$366

We would like to thank the Editor and two anonymous referees for very useful comments and suggestions.

Guglielmo Maria Caporale

Guglielmo-Maria.Caporale@brunel.ac.uk

1 Department of Accounting and Finance, University of Peloponnese, Kalamata, Greece

2 Department of Economics and Finance, Brunel University London, London UB8 3PH, UK 
billion (source: Investment Company Institute) in long-term registered investment companies, these being the largest investors in the US financial markets for much of the past 20 years. However, the exact nature of the dynamic linkages between mutual fund flows and stock market returns is yet to be investigated thoroughly (Edwards and Zhang 1998). There are two main approaches in the literature. The micro-approach analyses mutual fund flows on an individual basis and finds that investors typically move cash into the funds that had the highest returns in the preceding years [see e.g. Ippolito (1992), Sirri and Tufano (1993), and Hendricks et al. (1993), Rakowski and Wang (2009)]. By contrast, the macro-approach investigates the dynamic relationship between stock market returns and aggregate fund flows. Finance theory suggests that stock market returns and equity fund flows should be contemporaneously correlated, with positive market returns being linked to flows into equity funds, and negative returns to outflows or lower inflows instead.

Different explanations have been offered for the observed co-movement between these two variables. According to the feedback-trader hypothesis, market returns are the driving force behind trading and fund flows; in particular investors buy equity fund shares when stock prices increase and sell them when prices fall.

It is also possible, though, for fund flows to affect stock market returns as mutual fund investors may follow sentiment unrelated to fundamentals (Brown et al. 2003), and as a result of their uninformed demand stock prices may temporarily diverge from their fundamental values. This is the so-called price-pressure hypothesis, according to which fund flows cause stock market returns (Edelen and Warner 2001). A third hypothesis is that fund flows and market returns are both driven by the arrival of new information, without any direct causal linkage between them (Jank (2012)).

The present study is related to those of Warther (1995), Edwards and Zhang (1998), and Ben-Rephael et al. (2012) examining the Investment Company Institute (ICI) data on monthly aggregate flows to US mutual funds. If fund flows exert price pressure, fund managers will buy high "and sell low"; Edelen's (1999) showed that in fact mutual fund flows are responsible for their negative market timing. However, the existing literature mainly focuses on first-order causality. The only exception is the study by Cao et al. (2008), who estimated a VAR using daily data and found that daily market volatility is negatively related to contemporaneous and lagged flows; further, their impulse response analysis suggests that shocks to fund flows have a negative impact on market volatility. In their paper, volatility is measured first using high-frequency volatility estimators and then included in a bivariate model containing fund flows as well.

Our study is the first to examine directly the effects of the global financial crisis on the relationship between equity fund flows and stock market returns in the USA. It extends the analysis of Cao et al. (2008) and Lee et al. (2015) by allowing for parameter shifts in the context of a general econometric approach that sheds light on both level and volatility spillovers and also includes a number of control variables. More specifically, it models endogenously both the conditional mean and variance using a VAR-GARCH $(1,1)$-in-mean framework for which a BEKK representation is adopted given its well-known advantages (see below). The chosen specification also allows for possible effects of the second moments of the series on their first moments. Therefore, we are able to investigate causality-in-mean, causality-in-variance and GARCH-in- 
mean effects within the same framework and to shed new light on both mean and volatility spillovers between aggregate fund flows and stock returns. Our paper is also related to Yang and Bessler (2008) who investigated the existence of contagion among seven developed markets during the October 1987 crisis period, the most severe market crash among developed markets before the 2008 global financial crisis. Their results confirmed a propagation pattern from US market to the rest of the markets [see also $\mathrm{Xu}$ (2017) for another approach to analysing contemporaneous causal relationships based on error correction models and directed acyclic graphs].

Further, in the context of our analysis, we include a dummy variable allowing the parameters to shift in September 2008, at the time of the collapse of Lehman Brothers, since the recent global financial crisis could have affected the relationship between the two variables. It should be also noted that, according to the Investment Company Institute, over the 10 year period (2006-2015) US investors have increasingly moved towards equity funds that invest primarily in foreign markets (world equity funds), with net outflows totaling $\$ 834$ billion (source: Investment Company Institute) which makes an analysis of the dynamic linkages between domestic stock market returns and domestic equity fund flows particularly interesting. In brief, we find causality-in-mean from stock market returns to equity fund flows (consistently with the feedback-trading hypothesis) only in the post-September 2008 period. There are also volatility spillovers from stock market returns to equity fund flows both before and after the crisis; however, this relationship is not stable, becoming weaker in the crisis period. Following earlier studies arguing that mutual fund flows and stock market returns might be correlated through a common response to market-wide fundamentals (Jank 2012), we perform a robustness test by augmenting our model with a set of variables that predict the future state of the economy. In contrast to Jank (2012), we find that equity fund flows and stock market returns are not related to market-wide fundamentals. Overall, the inclusion of the control variables does not affect the main results.

The layout of the paper is as follows. Section 2 presents a brief literature review, while Sect. 3 outlines the econometric modeling approach. Section 4 describes the data and presents the empirical findings. Section 5 reports some robustness checks. Finally, Sect. 6 summarises the main findings and offers some concluding remarks.

\section{A brief literature review}

The literature on the relationship between fund flows and market returns is extensive and provides mixed evidence. Warther (1995) concluded that the relationship between aggregate fund flows and stock market returns in the USA depends on the data frequency. In particular, he found a positive or negative contemporaneous relationship depending on whether weekly or monthly data were employed. Remolona et al. (1997) estimated weak effects of short-term returns on mutual fund flows using an instrumental variable approach. Edwards and Zhang (1998) examined the causal relationship between fund flows and market returns in both stock and bond markets in the USA and concluded that there is unidirectional causality from market returns to aggregate equity and bond fund flows, whilst Mosebach and Najand (1999) found bidirectional causality between market returns and equity fund flows in the USA. Edelen 
and Warner (2001) reported a strong positive contemporaneous relationship between aggregate fund flows and stock market returns in the USA; moreover, their analysis based on daily data suggests that stock market returns contain information about future aggregate fund flows, but not vice versa. Jank (2012) attributed the evidence of a contemporaneous correlation between fund flows and aggregate market returns to a common response to macroeconomic news. Most recently, Qureshi et al. (2019) explored the interaction among mutual fund flows, stock market returns and macroeconomic variables for nine Asian developing economies. They employed a panel VAR framework providing evidence in favour of the feedback-trading hypothesis and the information-response hypothesis.

A few studies focus on countries other than the USA. For instance, Caporale et al. (2004) and Alexakis et al. (2005) identified a bidirectional dynamic relationship between equity fund flows and stock market returns in Greece. Oh and Parwada (2007) found positive, unidirectional causality running from stock market returns to mutual fund flows in Korea. Watson and Wickramanayake (2012) provided evidence consistent with the returns-chasing hypothesis for Australian funds. Alexakis et al. (2013) using an asymmetric cointegration method found bidirectional effects in a bull market, and unidirectional causality from fund flows to stock prices in a bear market in the case of Japan. The relationship between market return, market volatility and aggregate equity fund flow for ten international countries was the focus of the study of Lee et al. (2015). In their study, they employed a structural VAR approach and documented significant contemporaneous effects between the variables under consideration mainly for the USA.

Another interesting strand of the literature delves into the interaction between real estate mutual funds and real estate market returns. Ling and Naranjo (2003) analysed the influence of total equity flows into the REIT sector on aggregate REIT prices and returns, and also the impact of past industry-level returns on subsequent capital flows into the REIT sector. Ling and Naranjo (2006) examined the linkages between aggregate capital flows, dedicated REIT mutual funds and industry-level REIT returns. Neither paper found any systematic evidence in favour of the hypothesis that capital flows contain information on subsequent returns in the REIT sector. Ling et al. (2009) concluded that capital flows do not have a "price pressure" effect on property prices in the UK. In a related study, Fisher et al. (2009) reported that institutional investment flows in the previous period contain significant predictive ability over future returns in the case of private commercial real estate.

\section{The model}

We represent the first and second moments of stock market returns and fund flows using a VAR-GARCH $(1,1)$-in-mean ${ }^{1}$ In its most general specification, the model takes the following form:

$$
\boldsymbol{y}_{t}=\boldsymbol{\alpha}+\boldsymbol{\beta} \boldsymbol{y}_{t-1}+\delta h_{t-1}+\boldsymbol{u}_{t}
$$

\footnotetext{
1 The model is based on the GARCH(1, 1)-BEKK representation proposed by Engle and Kroner (1995).
} 
where $\boldsymbol{y}_{t}=\left(\right.$ MutualFund $d_{t}$, Stock $\left.\operatorname{Re} t_{t}\right)$ and $\boldsymbol{y}_{t-1}$ is a corresponding vector of lagged variables. The residual vector $\boldsymbol{u}_{t}=\left(u_{1, t}, u_{2, t}\right)$ is bivariate and normally distributed $\boldsymbol{u}_{t} \mid I_{t-1} \sim\left(\mathbf{0}, H_{t}\right)$ with its corresponding conditional variance covariance matrix given by:

$$
H_{t}=\left[\begin{array}{ll}
h_{11 t} & h_{12 t} \\
h_{12 t} & h_{22 t}
\end{array}\right]
$$

The parameter vectors of the mean return Eq. (1) correspond to the constant $\alpha=$ $\left(\alpha_{1}, \alpha_{2}\right)$, and the autoregressive term, $\boldsymbol{\beta}=\left(\beta_{11}, \beta_{12}+\beta_{12}^{*} \mid \beta_{21}+\beta_{21}^{*}, \beta_{22}\right)$, which allows for bidirectional causality effect, and the GARCH-in-mean parameters $\delta=$ $\left(\delta_{12}+\delta_{12}^{*} \mid \delta_{21}+\delta_{21}^{*}\right)$ which allows for bidirectional effects of volatilities on returns.

In order to account for the possible effects of the recent financial crisis, we include a dummy variable (denoted by *) with a switch in September 2008 (Lehman Brothers collapsed on the 15 of that month). Therefore, the second moment takes the following form $^{2}$ :

$$
H_{t}=C_{0}^{\prime} C_{0}+A_{11}^{\prime}\left[\begin{array}{cc}
u_{1, t-1}^{2} & u_{2, t-1} u_{1, t-1} \\
u_{1, t-1} u_{2, t-1} & u_{2, t-1}^{2}
\end{array}\right] A_{11}+G_{11}^{\prime} H_{t-1} G_{11}
$$

where

$$
A_{11}=\left[\begin{array}{cc}
a_{11} & a_{12}+a_{12}^{*} \\
a_{21}+a_{21}^{*} & a_{22}
\end{array}\right] ; \quad G_{11}=\left[\begin{array}{cc}
g_{11} & g_{12}+g_{12}^{*} \\
g_{21}+g_{21}^{*} & g_{22}
\end{array}\right]
$$

Equation (3) models the dynamic process of $H_{t}$ as a linear function of its own past values $H_{t-1}$ and past values of the squared innovations $\left(u_{1, t-1}^{2}, u_{2, t-1}^{2}\right)$. The parameters of (3) are given by $C_{0}$, which is restricted to be upper triangular, and the two matrices $A_{11}$ and $G_{11}$. The BEKK representation guarantees by construction that the covariance matrix in the system is positive definite. ${ }^{3}$ Given a sample of $T$ observations, a vector of unknown parameters $\theta$ and a $2 \times 1$ vector of variables $\boldsymbol{y}_{t}$, the conditional density function for model (1) is:

$$
f\left(\boldsymbol{y}_{t} \mid I_{t-1} ; \theta\right)=(2 \pi)^{-1}\left|H_{t}\right|^{-1 / 2} \exp \left(-\frac{\boldsymbol{u}_{t}^{\prime}\left(H_{t}^{-1}\right) \boldsymbol{u}_{t}}{2}\right)
$$

The log-likelihood function is:

$$
L=\sum_{t=1}^{T} \log f\left(\boldsymbol{y}_{t} \mid I_{t-1} ; \theta\right)
$$

\footnotetext{
2 The parameters $\left(a_{21}\right)$ and $\left(a_{11}\right)$ in Eq. (3) measure the causality effect of mutual funds and stock return volatility, respectively, whereas $\left(a_{21}+a_{21}^{*}\right)$ and $\left(a_{12}+a_{12}^{*}\right)$ the possible effect of the 2008 financial crisis.

3 Wavelet coherence, dynamic copulas, etc. are also very interesting methods that could be used; in particular, Xu (2018a, b) and Crowley and Hallett (2014) mention a number of important issues such as different time horizons and structural breaks that can be accommodated by wavelet transformations. However, such methods are more appropriate for higher-frequency data and this type of analysis is left for future work.
} 
where $\theta$ is the vector of unknown parameters. The standard errors are calculated using the quasi-maximum likelihood method of Bollerslev and Wooldridge (1992), which is robust to the distribution of the underlying residuals.

\section{Empirical analysis}

\subsection{Data}

Monthly data on aggregate equity fund flows have been obtained from the Investment Company Institute (ICI). Following other studies, flows are normalised using the previous month's aggregate assets. US stock market returns are proxied by the Wilshire 5000 Total market index over the period 2000:1-2015:8, for a total of 188 observations. We construct monthly returns as the logarithmic differences of stock prices and the first differences of fund flows.

Our aim is to analyse the determinants of the behaviour of mutual fund investors in the long run (as opposed to the short-run). For this purpose, we follow Warther (1995), Edwards and Zhang (1998), Fant (1999) and Ben-Rephael et al. (2012) that use monthly data on aggregate US funds provided by the Investment Company Institute (ICI).

Other studies using different frequencies report findings consistent with ours. In particular, Edelen and Warner (2001) found a strong positive contemporaneous relationship between aggregate fund flows and stock market returns by employing daily data, while Jank (2012) also documented a significant relationship between quarterly fund flows and market returns for US market.

The dataset available at the time the research was carried out ended in 2015 and is sufficiently long for our purposes. Extending the sample beyond 2015 would not add much to our analysis that is mainly focused on long-run considerations.

The descriptive statistics, presented in Table 1, Panel A, show that the 2008 crisis had a noticeable impact on the distribution of both variables. In particular, the volatility of stock returns increased post-September 2008, whereas for equity fund flows the opposite is true.

Furthermore, stock returns are higher in the post-September 2008 period, whilst equity flows have been negative during the same period (Fig. 1).

There exist various methods to choose the crisis period. For instance, some authors determine the crisis length on the basis of major economic and financial events published by official sources (e.g. Forbes and Rigobon 2002). Baur (2012) uses timelines provided by Federal Reserve Board of St. Louis (2010) among others to separate the global financial crisis (GFC) in four phases, on the basis of major key economic and financial events. Other studies use Markov regime switching models to identify the crisis period endogenously (e.g. Boyer et al. 2006). Finally, some studies specify the length of a crisis combining both a statistical and economic approach (Baur 2012).

In this paper, we have chosen the pre- and post-crisis periods in line with the recent literature and in particular the well-known study by Apergis et al. (2019), who examined contagion during the global financial crisis in the US and European financial markets. The collapse of Lehman Brothers was a pivotal event that affected all financial 
Table 1 Descriptive statistics

\begin{tabular}{|c|c|c|c|c|c|}
\hline & \multicolumn{3}{|l|}{$\underline{\text { Pre-2008 }}$} & \multicolumn{2}{|r|}{ Post-2008 } \\
\hline & Stock returns & \multicolumn{2}{|c|}{ Mutual funds } & Stock returns & Mutual funds \\
\hline \multicolumn{6}{|l|}{ Panel A } \\
\hline Mean & 0.115 & 0.193 & & 0.959 & -0.065 \\
\hline Median & 1.031 & 0.201 & & 1.710 & -0.017 \\
\hline SD & 4.186 & 0.437 & & 4.822 & 0.316 \\
\hline Skewness & -0.481 & \multicolumn{2}{|l|}{-0.866} & -0.824 & -1.192 \\
\hline Kurtosis & 2.956 & \multicolumn{2}{|l|}{6.195} & 4.794 & 6.244 \\
\hline Jarque-Bera & 4.001 & \multicolumn{2}{|l|}{57.251} & 20.544 & 56.071 \\
\hline Min. & -10.030 & \multicolumn{2}{|l|}{-1.722} & -17.611 & -1.446 \\
\hline Max. & 8.231 & \multicolumn{2}{|l|}{1.444} & 11.531 & 0.624 \\
\hline \multirow[t]{2}{*}{ No. Obs. } & 102 & \multicolumn{2}{|l|}{102} & 85 & 85 \\
\hline & \multicolumn{5}{|c|}{ Conditional correlations } \\
\hline Mean & 0.6585 & & & 0.4071 & \\
\hline \multirow[t]{3}{*}{ SD } & 0.1187 & & & 0.1611 & \\
\hline & \multicolumn{5}{|c|}{ Control variables } \\
\hline & $\triangle \mathrm{EPU}$ & $\Delta \mathrm{EMU}$ & TBill & $\Delta$ Default & $\Delta$ TSpread \\
\hline \multicolumn{6}{|l|}{ Panel B } \\
\hline Mean & 0.017 & 1.193 & 0.017 & 0.008 & 0.009 \\
\hline Median & -0.019 & 0.051 & 0.009 & 0.000 & -0.008 \\
\hline SD & 0.192 & 3.841 & 0.193 & 0.098 & 0.128 \\
\hline Skewness & 2.141 & 4.942 & 0.871 & 1.803 & 2.393 \\
\hline Kurtosis & 13.119 & 33.201 & 2.354 & 11.333 & 13.762 \\
\hline Jarque-Bera & 940.1 & 786.7 & 26.946 & 642.29 & 1081.1 \\
\hline Min. & -0.474 & -0.951 & 0.001 & -0.251 & -0.339 \\
\hline Max. & 1.231 & 30.547 & 0.061 & 0.566 & 0.747 \\
\hline No. Obs. & 187 & 187 & 187 & 187 & 187 \\
\hline
\end{tabular}

The sample size covers the period 2000:1-2015:8, for a total of 187 observations

markets and therefore it seems appropriate to select the corresponding date as the most likely breakpoint (whose significance we test by means of shift dummies) also in the case of the securities we are examining.

\subsection{Hypotheses tested}

We test for mean and volatility spillovers by imposing restrictions on the relevant parameters; specifically we consider the following three sets of null hypotheses ${ }^{4} H_{0}$ :

\footnotetext{
$\overline{4}_{\text {The joint restrictions } H_{05}-H_{08}}$ are tested by means of a Wald test.
} 


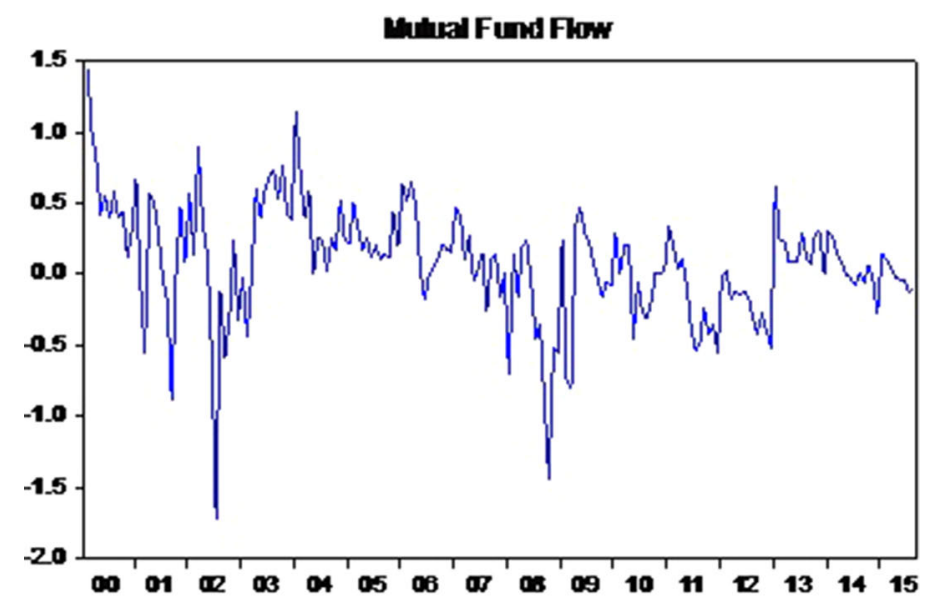

Stock HaktetRethms

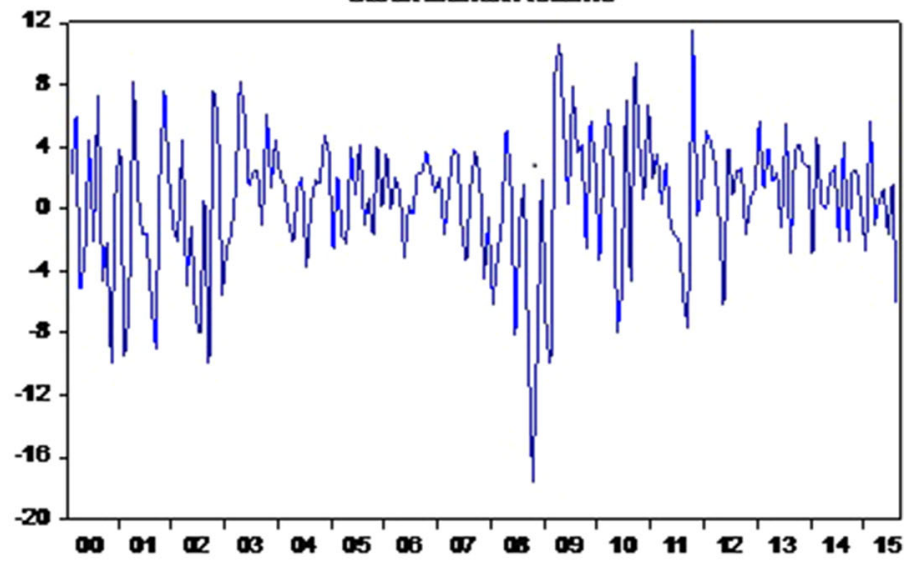

Contilinal Gorelations

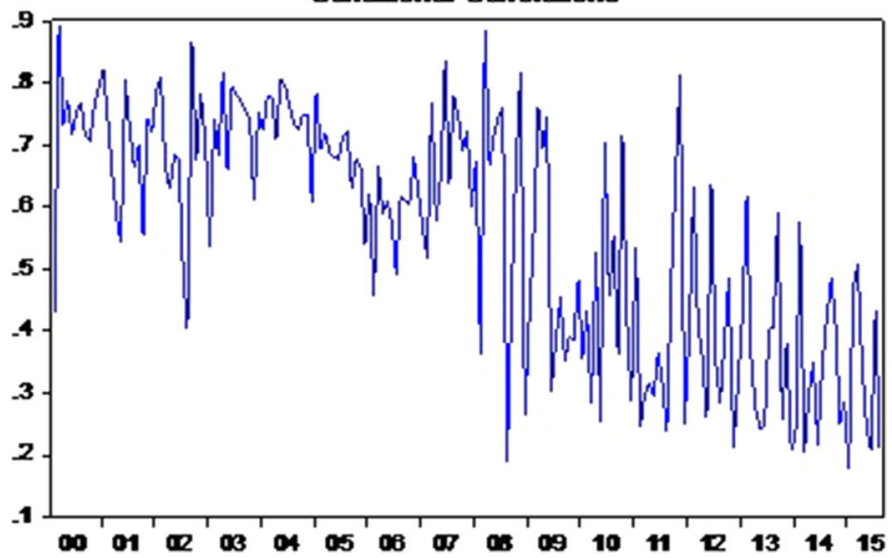

Fig. 1 Mutual fund flow, stock market returns and conditional correlations 
1. Tests of no mean spillovers between equity fund flows and stock returns

$\boldsymbol{H}_{01}$ : Equity fund flows on stock returns before the 2008 crisis: $\beta_{12}=0$

$\boldsymbol{H}_{02}$ : Equity fund flows on stock returns after the 2008 crisis: $\beta_{12}^{*}=0$

$\boldsymbol{H}_{03}$ : Stock returns on equity fund flows before the 2008 crisis: $\beta_{21}=0$

$\boldsymbol{H}_{04}$ : Stock returns on equity fund flows after the 2008 crisis: $\beta_{21}^{*}=0$

2. Tests of no volatility spillovers between equity fund flows and stock returns

$\boldsymbol{H}_{05}$ : Equity fund flows volatility on stock volatility before the 2008 crisis:

$a_{21}=g_{21}=0$

$\boldsymbol{H}_{06}$ : Equity fund flows volatility on stock volatility after the 2008 crisis: $a_{21}^{*}=$ $g_{21}^{*}=0$

$\boldsymbol{H}_{07}$ : Returns volatility on equity fund flows volatility before the 2008 crisis: $a_{12}=g_{12}=0$

$\boldsymbol{H}_{08}$ : Returns volatility on equity fund flows volatility after the 2008 crisis: $a_{12}^{*}=g_{12}^{*}=0$

3. Tests of no spillovers from volatility into returns (GARCH-in-mean effects)

$\boldsymbol{H}_{09}$ : Equity fund flows volatility on stock returns before the 2008 crisis: $\delta_{21}$ $=0$

$\boldsymbol{H}_{10}$ : Equity fund flows volatility on stock returns after the 2008 crisis: $\delta_{21}^{*}=0$

$\boldsymbol{H}_{11}$ : Stock returns volatility on equity fund flows before the 2008 crisis: $\delta_{12}$ $=0$

$\boldsymbol{H}_{12}$ : Stock returns volatility on equity fund flows after the 2008 crisis: $\delta_{12}^{*}=0$

\subsection{Discussion of the results}

In order to assess the adequacy of the models, Ljung-Box portmanteau tests were performed on the standardised and squared residuals. Overall, the results indicate that the VAR-GARCH $(1,1)$ specification captures satisfactorily the persistence in returns and squared returns of both variables. The estimated VAR-GARCH $(1,1)$ model with the associated robust $p$ values and likelihood function values are presented in Table 2. We select the optimal lag length of the mean equation using the Schwarz information criterion.

The following points are noteworthy. There does not appear to be any significant causality-in-mean at the standard 5\% level before the 2008 crisis. In the postSeptember 2008 period, causality running from stock markets returns to equity fund flows is found $\left(\beta_{12}^{*}=0.9478\right)$, consistently with the results of Remolona et al. (1997) and Edwards and Zhang (1998). This supports the feedback-trading hypothesis that implies that equity fund investors respond to positive returns with inflows and to negative returns with outflows.

The model specification allows us to control and test for the presence of reverse causality running from volatility to returns (GARCH-in-mean effects), which is measured by the parameter vector $\delta$. We only find a significant (positive) effect from stock markets returns to equity fund flows $\left(\delta_{12}=0.0349\right)$. The 2008 cri- 
sis seems to have affected the relationship between stock market volatility and equity fund flows, with a negative effect of the former on the latter post-September $2008\left(\delta_{12}+\delta_{12}^{*}=-0.0164\right)$. This points to a shift in the risk appetite of US equity fund investors, who appear to have reduced their degree of exposure in the context of a more volatile stock market. The volatility of equity fund flows does not appear to affect stock market returns post-September 2008 either.

Concerning the conditional variance equations, the estimated "own-market" coefficients are statistically significant with $g_{11}=0.4862$ and $g_{22}=0.9784$ suggesting a high degree of persistence, especially in the case of stock market returns. Their volatility has a significant influence on that of equity fund flows both before $\left(g_{21}=-0.0455\right)$ and after the crisis $\left(g_{21}+g_{21}^{*}=-0.0084\right)$, but it is smaller in the latter period. There is no evidence of causality-in-variance in the opposite direction. Squared stock market returns have a significant influence on the volatility of equity fund flows before the crisis $\left(a_{12}=-3.9733\right)$. Squared equity fund returns also affect the volatility of stock market returns before the crisis $\left(a_{21}=0.0872\right)$. Furthermore, there is evidence of this affecting the causality-in-variance dynamics. In particular, the post-crisis coefficient on squared stock market returns is lower, in absolute value $\left(a_{12}+a_{12}^{*}=-0.6535\right)$, compared to the pre-September 2008 period. The same is true of the coefficient on squared equity fund returns that falls $\left(a_{21}+a_{21}^{*}=0.0553\right)$.

Finally, the conditional correlations confirm the previous results. While they are positive for the whole sample, they shift downward in the post-September 2008 period, when they have an average value of 0.4071 compared to 0.6585 in the earlier period. Furthermore, their standard deviation increases from 0.1187 in the earlier period to 0.1611 in the following one (see Table 1), which is further evidence of a regime shift. The interaction between fund flows and stock market returns detected in the two subperiods could be rationalised as follows. The demand for equity mutual funds strongly depends on demographics that evolve over time and on investors' response to shifts in domestic and foreign financial and economic conditions.

In the past decade, US investors have witnessed two of the worst bear markets since the Great Depression. As a result of this negative development, domestic US equity funds have experienced significant outflows in the period 2002-2003 and later for seven consecutive years (2006-2012), which led to outflows totaling \$613 billion. However, US households did not turn their back completely on the stock market. Investors favoured equity funds by shifting the composition of their portfolio through their participation in pension schemes. In particular, the portion of participants who remained away from equity investments in their 401(k) accounts substantially declined over the 10-year period from 2001 to 2011. This might explain the absence of a significant relationship between fund flows and market returns during the pre-crisis period. Another factor that might have contributed to this phenomenon is that the largest portion of US long-term mutual fund assets is held by individual investors who admittedly are less sensitive to market events than institutional investors. Moreover, households often use mutual funds for long-term saving purposes by adding a regular amount of money every month. Our finding concerning the post-crisis period with respect to market volatility and flows is corroborated by the annual report published by the annual Investment Company Institute (ICI) Factbook for 2015 that states: 
Table 2 Estimated VAR-GARCH $(1,1)$ model

\begin{tabular}{|c|c|c|c|c|c|}
\hline \multicolumn{3}{|c|}{ Pre-crisis } & \multicolumn{3}{|c|}{ Post-crisis } \\
\hline Par. & Coefficient & $p$ values & Par. & Coefficient & $p$ values \\
\hline \multicolumn{6}{|c|}{ Conditional mean equation } \\
\hline$\alpha_{1}$ & 0.0157 & $(0.7506)$ & & & \\
\hline$\alpha_{2}$ & 1.3313 & $(0.0569)$ & & & \\
\hline$\beta_{11}$ & 0.4618 & $(0.0001)$ & & & \\
\hline \multirow[t]{2}{*}{$\beta_{12}$} & -0.1449 & $(0.8688)$ & & & \\
\hline & 0.0088 & $(0.4539)$ & $\beta_{12}^{*}$ & 0.9478 & $(0.0004)$ \\
\hline$\beta_{21}$ & & & $\beta_{21}^{*}$ & 0.0078 & $(0.5539)$ \\
\hline$\beta_{22}$ & -0.0791 & $(0.4051)$ & & & \\
\hline \multirow[t]{2}{*}{$\delta_{12}$} & 0.0349 & $(0.0141)$ & & & \\
\hline & & & $\delta_{12}^{*}$ & -0.0513 & $(0.0001)$ \\
\hline$\delta_{21}$ & -0.5731 & $(0.7717)$ & $\delta_{21}^{*}$ & -0.7795 & $(0.5819)$ \\
\hline \multicolumn{6}{|c|}{ Conditional variance equation } \\
\hline$c_{11}$ & 0.1512 & $(0.0001)$ & & & \\
\hline$c_{12}$ & 0.1553 & $(0.0038)$ & & & \\
\hline$c_{22}$ & 0.0001 & $(0.0009)$ & & & \\
\hline$g_{11}$ & 0.4862 & $(0.0002)$ & & & \\
\hline \multirow[t]{2}{*}{$g_{21}$} & -0.0445 & $(0.0001)$ & & & \\
\hline & 0.8845 & $(0.2688)$ & $g_{21}^{*}$ & 0.0361 & $(0.0009)$ \\
\hline$g_{12}$ & & & $g_{12}^{*}$ & 3.1591 & $(0.4061)$ \\
\hline$g_{22}$ & 0.9784 & $(0.0001)$ & & & \\
\hline$a_{11}$ & -0.2799 & $(0.0285)$ & & & \\
\hline \multirow[t]{2}{*}{$a_{21}$} & 0.0872 & $(0.0001)$ & & & \\
\hline & & & $a_{21}^{*}$ & -0.0319 & (0.0193) \\
\hline \multirow[t]{2}{*}{$a_{12}$} & -3.9733 & $(0.0001)$ & & & \\
\hline & & & $a_{12}^{*}$ & 3.3188 & $(0.0212)$ \\
\hline$a_{22}$ & 0.1173 & $(0.0002)$ & & & \\
\hline LogLik & -514.1839 & & & & \\
\hline
\end{tabular}


Table 2 continued

\begin{tabular}{|c|c|c|c|c|}
\hline \multicolumn{2}{|l|}{ Pre-crisis } & \multicolumn{3}{|l|}{ Post-crisis } \\
\hline Coefficient & $p$ values & Par. & Coefficient & $p$ values \\
\hline $\mathrm{LB}_{\text {Mutual,(10) }}$ & 14.419 & $\mathrm{LB}_{\text {Stock, (10) }}$ & 12.573 & \\
\hline LB $_{\text {Mutual,(10) }}$ & 1.714 & $\mathrm{LB}_{\text {Stock, (10) }}$ & 4.497 & \\
\hline
\end{tabular}

$p$ values are calculated using the quasi-maximum likelihood method of Bollerslev and Wooldridge (1992), which is robust to the distribution of the underlying residuals. Parameters not statistically significant at 5\% level are not reported. LB $(10)$ and $\mathrm{LB}_{(10)}^{2}$ are the Ljung-Box test (1978) of significance of autocorrelations of ten lags in the standardised and standardised squared residuals, respectively. The parameters $\beta_{12}$ and $\beta_{21}$ measure the causality effect of mutual funds flow on stock returns and of stock returns on mutual funds flow, respectively,.$_{21}$ and $a_{12}$ measure the causality-in- variance effect. The effect of the 2008 financial crises on stock returns is measured by $\left(\beta_{12}+\beta_{12}^{*}\right)$, and on mutual funds flow by $\left(\beta_{21}+\beta_{21}^{*}\right)$ whereas $\left(a_{21}+a_{21}^{*}\right)$ and $\left(a_{12}+a_{12}^{*}\right)$ capture the effect on stock return volatilities and mutual funds flow volatilities. The covariance stationarity condition is satisfied by all the estimated models, all the eigenvalues of $A_{11} \otimes A_{11}+G_{11} \otimes G_{11}$ being less than one in modulus. Note that in the conditional variance equation, the sign of the parameters cannot be determined

"Outflows from equity funds late in the year were likely related, in part, to market volatility".

\section{Robustness check}

According to the information-response hypothesis, the documented relationship between stock market returns and equity fund flows could be just the result of both variables responding to the arrival of new information (Jank 2012). In order to test this hypothesis, we augment the baseline specification with a set of control variables in the conditional mean equation (Eq.1): the US Economic Policy Uncertainty Index (EPU) and the US Equity market uncertainty index (EMU) that are obtained from the site http://www.policyuncertainty.com/; the three-month Treasury Bill rate (TBill), the Term spread (Aaa corporate bond yield minus the 3-month bill yieldTSpread), and the Default spread (Baa corporate bond yield minus the Aaa corporate bond yield-Default), both from Moody's - these series are taken from the Federal Reserve of Saint Louis (FRED) Database. The US Economic Policy Uncertainty index attempts to capture policy-related economic uncertainty that stems from three different sources: newspaper coverage of policy-related economic uncertainty, the number of Federal tax code provisions expiring in the coming years and disagreement between economic forecasters. Baker et al. (2015) argue that shifts in their policy uncertainty index are associated with greater stock price volatility and their index appears to have predictive power for future output, investment and unemployment in the USA. The stock market uncertainty index is instead constructed employing news articles from leading US newspapers with a focus on the stock market.

Proponents of the information-response hypothesis argue that equity fund investors adjust their strategies on the basis of new information which is also fully incorporated into prices in an efficient market; consequently, the demand for equity fund shares should shift in response to news about fundamentals, and equity fund flows should 
be driven by such news. (By contrast, according to the price-pressure hypothesis, there should be no relationship between flows and news.) Therefore, the informationresponse hypothesis has two testable implications (Jank 2012): First, variables that contain information about the future state of the economy should be related to equity fund flows; second, if the latter respond to the arrival of information about the real economy, then they should also predict real economic activity. In the present study, we test the first of the two hypotheses. All variables are lagged and differenced once before being included in the model, with the exception of the Treasury Bill rate (lagged but not in first differences); descriptive statistics are presented in Table 1, Panel B. The extended specification has the following form:

$$
\boldsymbol{y}_{t}=\boldsymbol{\alpha}+\boldsymbol{\beta} \boldsymbol{y}_{t-1}+\boldsymbol{\delta} h_{t-1}+\boldsymbol{\gamma} z_{t-1}+\boldsymbol{u}_{t}
$$

where $\boldsymbol{y}_{t}=\left(\right.$ MutualFund ${ }_{t}$, Stock $\left.\operatorname{Re} t_{t}\right), \boldsymbol{y}_{t-1}$ is the corresponding vector of lagged variables and $z_{t-1}$ is the matrix containing the lagged control variables. Therefore, $\gamma^{\prime}=\left(\gamma_{11}, \gamma_{12}, \gamma_{13}, \gamma_{14}, \gamma_{15} \mid \gamma_{21}, \gamma_{22}, \gamma_{23}, \gamma_{24}, \gamma_{25}\right)$ is the matrix of control parameters $^{5}$ that appear in both equations. The conditional variance equation is the same as before (see Eq. 2).

Overall, the new set of results confirms the previous ones as far as the dynamics linkages between equity funds to stock returns are concerned. Further, they do not support Jank's (2012) hypothesis that market returns and equity fund flows react simultaneously to macroeconomic news. More specifically, we find that the Economic Policy Uncertainty Index has a positive effect on equity fund flows; this could reflect a preference on the part of investors for professionally managed collective schemes over individual stock market investments when uncertainty about the future state of the economy grows. On the other hand, default spread has the expected negative effect on stock market returns (Table 3).

\section{Conclusions}

This paper examines the effects of the global financial crisis on the relationship between equity fund flows and stock market returns in the US employing monthly data for the period January 2000-August 2015. In particular, a VAR-GARCH-in-mean model with a BEKK representation is estimated to test for both mean and volatility spillovers; the specification also includes a switch dummy to take into account the possible effects of the crisis. We find statistically significant causality-in-mean running from stock market returns to equity fund flows in the post-September 2008 period only. This finding lends support to the feedback-trading hypothesis over that period. Net flows to equity funds tend to rise with stock prices and the opposite tends to occur when stock prices fall. Cao et al. (2008) had concluded that daily market volatility is negatively related to concurrent and lagged aggregate flows. Our study shows that the crisis significantly

\footnotetext{
5 These variables are treated as exogenous in order to obtain a system of equations of manageable dimensions; they are lagged in order to control for any potential endogeneity and to capture possible noncontemporaneous effects. Please note that a switch dummy was not included for the control variables, again in order to reduce the number of parameters to be estimated.
} 
Table 3 Estimated VAR-GARCH $(1,1)$ model with control variables

\begin{tabular}{|c|c|c|c|c|c|}
\hline \multicolumn{3}{|l|}{ Pre-crisis } & \multicolumn{3}{|l|}{ Post-crisis } \\
\hline Par. & Coefficient & $p$ values & Par. & Coefficient & $p$ values \\
\hline \multicolumn{6}{|c|}{ Conditional mean equation } \\
\hline$\alpha_{1}$ & -0.0262 & $(0.4936)$ & & & \\
\hline$\alpha_{2}$ & 0.8955 & $(0.0936)$ & & & \\
\hline$\beta_{11}$ & 0.5414 & $(0.0001)$ & & & \\
\hline \multirow[t]{2}{*}{$\beta_{12}$} & 0.3773 & $(0.6647)$ & & & \\
\hline & 0.0056 & $(0.4125)$ & $\beta_{12}^{*}$ & 0.1481 & $(0.0423)$ \\
\hline$\beta_{21}$ & & & $\beta_{21}^{*}$ & 0.0043 & $(0.5254)$ \\
\hline$\beta_{22}$ & -0.1070 & $(0.1893)$ & & & \\
\hline \multirow[t]{2}{*}{$\delta_{12}$} & 0.0355 & $(0.0031)$ & & & \\
\hline & -1.7205 & $(0.3181)$ & $\delta_{12}^{*}$ & -0.0334 & $(0.0013)$ \\
\hline$\delta_{21}$ & & & $\delta_{21}^{*}$ & 2.3514 & $(0.2038)$ \\
\hline \multicolumn{3}{|c|}{ Control on mutual fund } & \multicolumn{3}{|c|}{ Control on stock returns } \\
\hline$\gamma_{11}\left(\Delta \mathrm{EPU}_{t-1}\right)$ & 0.0024 & $(0.0278)$ & $\gamma_{21}\left(\Delta \mathrm{EPU}_{t-1}\right)$ & 0.0235 & $(0.2001)$ \\
\hline$\gamma_{12}\left(\Delta \mathrm{EMU}_{t-1}\right)$ & 0.0001 & $(0.3547)$ & $\gamma_{22}\left(\Delta \mathrm{EMU}_{t-1}\right)$ & 0.0003 & $(0.3721)$ \\
\hline$\gamma_{13}\left(\mathrm{TBill}_{t-1}\right)$ & -0.0031 & $(0.7563)$ & $\gamma_{23}\left(\operatorname{TBill}_{t-1}\right)$ & -0.0215 & $(0.8677)$ \\
\hline$\gamma_{14}\left(\Delta\right.$ Default $\left._{t-1}\right)$ & 0.0045 & $(0.0903)$ & $\gamma_{24}\left(\Delta\right.$ Default $\left._{t-1}\right)$ & -0.0861 & $(0.0225)$ \\
\hline$\gamma_{15}\left(\Delta \operatorname{TSpread}_{t-1}\right)$ & 0.0011 & $(0.3159)$ & $\gamma_{25}\left(\Delta \operatorname{TSpread}_{t-1}\right)$ & -0.0172 & $(0.2754)$ \\
\hline \multicolumn{6}{|c|}{ Conditional variance equation } \\
\hline$c_{11}$ & -0.1087 & $(0.0001)$ & & & \\
\hline$c_{12}$ & 0.6351 & $(0.0081)$ & & & \\
\hline$c_{22}$ & -0.0001 & $(0.0009)$ & & & \\
\hline$g_{11}$ & 0.1646 & $(0.0102)$ & & & \\
\hline \multirow{2}{*}{$g_{21}$} & 0.0585 & $(0.0101)$ & & & \\
\hline & 0.5992 & $(0.3725)$ & $g_{21}^{*}$ & -0.0410 & $(0.0032)$ \\
\hline$g_{12}$ & & & $g_{12}^{*}$ & -2.8891 & (0.1883) \\
\hline$g_{22}$ & 0.8555 & $(0.0001)$ & & & \\
\hline$a_{11}$ & 0.9353 & $(0.0001)$ & & & \\
\hline \multirow[t]{2}{*}{$a_{21}$} & -0.0499 & $(0.0061)$ & & & \\
\hline & & & $a_{21}^{*}$ & 0.0305 & $(0.0111)$ \\
\hline \multirow[t]{2}{*}{$a_{12}$} & -2.3773 & $(0.0162)$ & & & \\
\hline & & & $a_{12}^{*}$ & 6.4028 & $(0.0083)$ \\
\hline$a_{22}$ & 0.5298 & $(0.0001)$ & & & \\
\hline LogLik & -502.7511 & & & & \\
\hline
\end{tabular}


Table 3 continued

\begin{tabular}{|c|c|c|c|c|c|}
\hline \multicolumn{3}{|c|}{ Pre-crisis } & \multicolumn{3}{|c|}{ Post-crisis } \\
\hline Par. & Coefficient & $p$ values & Par. & Coefficient & $p$ values \\
\hline \multicolumn{2}{|c|}{ LB $_{\text {Mutual,(10) }}$} & 10.331 & \multicolumn{2}{|c|}{ LB $_{\text {Stock, (10) }}$} & 9.443 \\
\hline \multicolumn{2}{|c|}{ LB $_{\text {Mutual,(10) }}$} & 5.169 & \multicolumn{2}{|c|}{ LB $_{\text {Stock, (10) }}$} & 3.981 \\
\hline
\end{tabular}

See notes Table 2. EPU, EMU, TBill, TSpread and Default are, respectively, the US Economic Policy Uncertainty Index, the US Equity market uncertainty index, three months Treasury Bills, Term spread by Moody's Aaa corporate bond yield minus the three-month bill yield and the Default spread by Moody's Baa corporate bond yield minus the Aaa corporate bond yield

affected the relationship between the two series. In particular, the GARCH-in-mean effects of stock market volatility on equity fund flows turned from positive before the crisis to negative post-September 2008. Further, the volatility of stock market returns has a significant influence on that of equity fund flows both before and after the crisis, but less so in the latter period, namely the relationship is not stable over time. Finally, we carry out robustness checks by including in the model exogenous factors, namely the US Economic Policy Uncertainty Index, the US Equity market uncertainty index, the three-month Treasury Bill rate and Moody's Term spread and Default spread. The augmented model yields very similar findings and lends support to the price-pressure rather than information-response hypothesis. This evidence can be usefully exploited by both policy makers and market participants for their respective purposes.

The response of investors' demand for mutual funds to previous stock market returns and its effects on returns could undermine the stability of capital markets. Stated differently, the effect of mutual fund trading on the behaviour of market prices remains central to market efficiency, which requires stock prices to respond to changes in the relevant fundamental or macroeconomic factors. Therefore, as Edwards and Zhang (1998) point out, mutual fund flows, regardless of their magnitude, should have no effect on equilibrium asset prices or returns independently of shifts in fundamentals. In other words, a bull or bear market might be just the result of excessive mutual fund trading without a significant fundamental or economic factor behind it. Therefore, mutual fund investors should be cautious when processing market information before they make their investment decisions. Moreover, policy makers should be concerned with the interaction between mutual fund flows and markets and implement the necessary policies in order to preserve market stability.

Open Access This article is distributed under the terms of the Creative Commons Attribution 4.0 International License (http://creativecommons.org/licenses/by/4.0/), which permits unrestricted use, distribution, and reproduction in any medium, provided you give appropriate credit to the original author(s) and the source, provide a link to the Creative Commons license, and indicate if changes were made.

\section{References}

Alexakis C, Niarchos N, Patra T, Poshakwale S (2005) The dynamics between stock returns and mutual fund flows: empirical evidence from the Greek market. Int Rev Financ Anal 14:559-569 
Alexakis C, Dasilas A, Grose C (2013) Asymmetric dynamic relations between stock prices and mutual fund units in Japan: an application of hidden cointegration technique. Int Rev Financ Anal 28:1-8

Apergis N, Christou C, Kinigakis I (2019) Contagion across US and European financial markets: evidence from the CDS markets. J Int Money Finance 96:1-12

Baker S, Bloom N, Davis S (2015) Measuring economic policy uncertainty. NBER working paper 21633, Cambridge, MA

Baur D (2012) Financial contagion and the real economy. J Bank Finance 36(10):2680-92

Ben-Rephael A, Kandel S, Wohl A (2012) Measuring investor sentiment with mutual fund flows. J Financ Econ 104:363-382

Bollerslev T, Wooldridge JM (1992) Quasi-maximum likelihood estimation and inference in dynamic models with time varying covariances. Econom Rev 11:143-172

Boyer BH, Kumagai T, Yuan K (2006) How do crises spread? Evidence from accessible and inaccessible stock indices. J Finance 66(2):957-1003

Brown SJ, Goetzmann WN, Hiraki T, Shirishi N, Watanabe M (2003) Investor sentiment in Japanese and U.S. Daily Mutual Fund Flows. NBER working paper no 9470

Cao C, Chang EC, Wang Y (2008) An empirical analysis of the dynamic relationship between mutual fund ow and market return volatility. J Bank Finance 32:2111-2123

Caporale G, Philippas N, Pittis N (2004) Feedbacks between mutual fund flows and security returns: evidence from the Greek capital market. Appl Financ Econ 14:981-989

Crowley PM, Hallett A-H (2014) The great moderation under the microscope: decomposition of macroeconomic cycles in US and UK aggregate demand. In: Wavelet applications in economics and finance. Springer, Cham, pp 47-71

Edelen RM (1999) Investor flows and the assessed performance of open-end mutual funds. J Financ Econ 53(3):439-466

Edelen R, Warner J (2001) Aggregate price effects of institutional trading: a study of mutual fund flow and market returns. J Financ Econ 59:195-220

Edwards F, Zhang X (1998) Mutual funds and stock and bond market stability. J Financ Serv Res 13:257-282

Engle RF, Kroner KF (1995) Multivariate simultaneous generalized ARCH. Econom Theory 11:122-150

Fant LF (1999) Investment behavior of mutual fund shareholders: the evidence from aggregate fund flows. J Financ Mark 2(4):391-402

Fisher J, Ling DC, Naranjo A (2009) Institutional capital flows and return dynamics in private commercial real estate markets. Real Estate Econ 37(1):85-116

Federal Reserve Board of St. Louis. (2010) The financial crisis: A timeline of events and policy actions. St. Louis

Forbes K, Rigobon R (2002) No contagion, only interdependence: measuring stock market comovements. J Finance 57:2223-2673

Hendricks D, Patel J, Zeckhauser R (1993) Hot hands in mutual funds: short-run persistence of relative performance, 1974-1988. J Finance 48(1):93-130

Investment Company Institute (2015) Mutual fund fact book: a review of trends and activity in the Investment Company Industry, 55th edn. Investment Company Institute, Washington

Ippolito RA (1992) Consumer reaction to measures of poor quality: evidence from the mutual fund industry. J Law Econ 35:45-70

Jank S (2012) Mutual fund flows, expected returns, and the real economy. J Bank Finance 36:3060-3070

Lee BS, Paek M, Ha Y, Ko K (2015) The dynamics of market volatility, market return, and equity fund flow: international evidence. Int Rev Econ Finance 35:214-227

Ling DC, Naranjo A (2003) The dynamics of REIT capital flows and returns. Real Estate Econ 31(3):405436

Ling DC, Naranjo A (2006) Dedicated REIT mutual fund flows and REIT performance. J Real Estate Finance Econ 32(4):409-433

Ling D, Marcato G, McAllister P (2009) The dynamics of asset prices, capital flows, and transaction activity in illiquid, informational inefficient, commercial real estate markets. J Real Estate Finance Econ 39(3):359-383

Ljung GM, Box GEP (1978) On a measure of lack of fit in time series models. Biometrika 65:297-303

Mosebach M, Najand M (1999) Are the structural changes in mutual funds investing driving the US stock market to its current level. J Financ Res 22:317-329

Oh N, Parwada J (2007) Relations between mutual fund flows and stock market returns in Korea. J Int Financ Mark Inst Money 17:140-151 
Qureshi F, Kutan A, Ghafoor A, Khan HH, Qureshi Z (2019) Dynamics of mutual funds and stock markets in Asian developing economies. J Asian Econ. https://doi.org/10.1016/j.asieco.2019.101135

Rakowski D, Wang X (2009) The dynamics of short-term mutual fund flows and returns: a time-series and cross-sectional investigation. J Bank Finance 33(11):2102-2109

Remolona EM, Kleiman P, Gruenstein D (1997) Market returns and mutual fund flow. Econ Policy Rev $3: 33-52$

Sirri ER, Tufano P (1993) Buying and selling mutual funds: flows, performance, fees, and services, Working paper, Harvard Business School

Warther V (1995) Aggregate mutual fund flows and security returns. J Financ Econ 39:209-235

Watson J, Wickramanayake J (2012) The relationship between aggregate managed fund flows and share market returns in Australia. J Int Financ Mark Inst Money 22:451-472

Xu X (2017) Contemporaneous causal orderings of US corn cash prices through directed acyclic graphs. Empir Econ 52(2):731-758

$\mathrm{Xu}$ X (2018a) Intraday price information flows between the CSI300 and futures market: an application of wavelet analysis. Empir Econ 54:1267-1295

$\mathrm{Xu}$ X (2018b) Causal structure among US corn futures and regional cash prices in the time and frequency domain. J Appl Stat 45(13):2455-2480

Yang J, Bessler D (2008) Contagion around the October 1987 stock market crash. Eur J Oper Res 184:291310

Publisher's Note Springer Nature remains neutral with regard to jurisdictional claims in published maps and institutional affiliations. 